\title{
Research advances on the immune research and prospect of immunotherapy in pituitary adenomas
}

\author{
Ding Nie ${ }^{1}$, Qiuyue Fang ${ }^{2}$, Bin $\mathrm{Li}^{2}$, Jianhua Cheng ${ }^{1}$, Chuzhong $\mathrm{Li}^{2}$, Songbai Gui', Yazhuo Zhang ${ }^{2}$ and Peng Zhao ${ }^{\text {** }}$
}

\begin{abstract}
Background: Pituitary adenomas are one type of intracranial tumor, which can be divided into microadenoma $(\leq 1$ $\mathrm{cm})$, macroadenoma $(>1 \mathrm{~cm})$, and giant adenoma $(\geq 4 \mathrm{~cm})$ according to their diametral sizes. They are benign, typically slow-progressing, whereas the biological behavior of some of them is invasive, which presents a major clinical challenge. Treatment of some pituitary adenomas is still difficult due to drug resistance or multiple relapses, usually after surgery, medication, and radiation. At present, no clear prediction and treatment biomarkers have been found in pituitary adenomas and some of them do not cause clinical symptoms, so patients are often found to be ill through physical examination, and some are even found through autopsy. With the development of research on pituitary adenomas, the immune response has become a hot spot and may serve as a novel disease marker and therapeutic target.

The distribution and function of immune cells and their secreted molecules in pituitary adenomas are extremely complex. Researchers found that infiltration of immune cells may have a positive effect on the treatment and prognosis of pituitary adenomas. In this review, we summarized the advance of tumor immunity in pituitary adenomas, revealing the immunity molecules as potential biomarkers as well as therapeutic agents for pituitary adenomas.

Conclusion: The immune studies related to pituitary adenomas may help us find relevant immune markers. At the same time, the exploration of immunotherapy also provides new options for the treatment of pituitary adenomas.
\end{abstract}

\section{Introduction}

Pituitary adenomas (PAs) are benign intracranial tumors with the third highest incidence, accounting for about $10-15 \%$ of intracranial tumors [1]. However, up to $20 \%$ of PAs appear clinically invasive symptoms, showing rapid growth and recurrence after treatment $[2,3]$. More seriously, studies have shown that $0.2 \%$ of PAs are more likely to become pituitary cancer [4]. PAs can lead to clinical symptoms by oppressing the normal pituitary gland and invading the cavernous sinus or skull base

\footnotetext{
* Correspondence: zhaopeng@ccmu.edu.cn

'Department of Neurosurgery, Beijing Tiantan Hospital, Capital Medical University, Beijing, China

Full list of author information is available at the end of the article
}

structure. In addition, a variety of "functioning" PAs secrete supraphysiologic levels of hormones, resulting in profound systemic effects that reflect the changes in hormone levels [5]. At present, the treatment of PAs mainly depends on surgical resection [6]. However, the complete resection rate of tumors is only 66 to 78\% [7]. When surgery and chemotherapy fail, radiotherapy becomes the treatment of choice against PAs. But radiation strikes at healthy tissue. For example, it can lead to visual impairment, hypopituitary, and cerebrospinal fluid leakage. Therefore, this clinical dilemma has inspired researchers to find new markers and treatment methods $[8,9]$. With the deepening understanding of the tumor environment and its development, immunotherapy is a 
promising alternative therapy for the treatment of drugresistant or recurrent PAs [9]. The mechanism of PAs occurrence and development is still unclear, which may be a result of multiple factors such as epigenetics, genes, and tumor microenvironment(TME) $[10,11]$. The TME is a special environment generated by the interaction between tumor cells and the host during tumor development [12]. It is a complex environment consisting of fibroblasts, myofibroblasts, endothelial cells, immune cells, and extracellular matrix (ECM) which can affect tumor proliferation, invasiveness, and angiogenesis [13, 14]. Current research has focused on immune cells in TME. A tumor is a systemic disease in which inflammatory immune cells, chemokines, and cytokines influence tumor growth and invasion [15]. The infiltrating immune cells in brain tissue include macrophages, neutrophils, T cells, natural killer cells(NK cells), and other immune cells. Recent studies have shown that they play an important role in brain function and physiology; they can influence behavior and participate in the pathogenesis of various neuropathologies [16]. Myeloid cells, such as tumor-associated macrophages, dendritic cells, and lymphocytes, such as $\mathrm{T}$ cells and $\mathrm{B}$ cells, make up the tumor microenvironmental immune cells (TMICs) (Fig. 1) [17]. They may be located in the core, margin, or adjacent tertiary lymphoid structures (TLS) of the tumor [18]. The role of these infiltrating immune cells and their secreted molecules is complex and can ultimately lead to tumor-promoting or anti-tumor effects through interaction with the tumor and its host $[19,20]$. There are still few studies on the immunity of pituitary adenoma. In this review, we summarize the current immunological studies on pituitary adenoma to point out the prospect that immunity molecules may be helpful to prognosis prediction and clinical targeted therapy.

\section{Immune cells infiltrate in PAs}

Innate immunity (non-specific immunity) and adaptive immunity(specific immunity)comprise the human immune system, and adaptive immunity involves $\mathrm{T}$ and $\mathrm{B}$ cells and their secreted factors [21]. As part of the natural immune cell population, NK cells can control tumor growth by interacting with other immune cells and tumor cells $[22,23]$. For example, MHC-I offer $\mathrm{CD} 8^{+} \mathrm{T}$ lymphocytes cell antigens, such as from its protein and virus protein antigen, and extracellular antigen by $\mathrm{MHC}$ II usually provided to $\mathrm{CD}_{4}^{+} \mathrm{T}$ lymphocyte, loss of MHCI during the process of tumor formation is one typical method that cancer cells evade monitoring of $\mathrm{CD} 8^{+} \mathrm{T}$ cells, NK cells express to identify MHC-I moleculesinhibition of cell surface receptors, and eliminate cannot fully express a large number of MHC-I molecular targets [24-26]. Current studies have shown that although the number of NK cells in solid tumors is smaller than that of $\mathrm{CD}^{+} \mathrm{T}$ cells, $\mathrm{CD} 4^{+} \mathrm{T}$ cells, and $\mathrm{B}$ cells, the presence of NK cells in TME may be associated with a good prognosis [27, 28]. Macrophages can be polarized into M1 or M2 macrophages. Tumor-associated macrophages(TAMs) are generally characterized as M2-like macrophages [29]. By stimulating tumor angiogenesis and inhibiting the anti-tumor immune response mediated by $\mathrm{T}$ cells, TAMs promote the proliferation, invasion, and metastasis of tumor cells [30]. Recent studies by Zhang et al. have shown that PA may produce excess lactate,

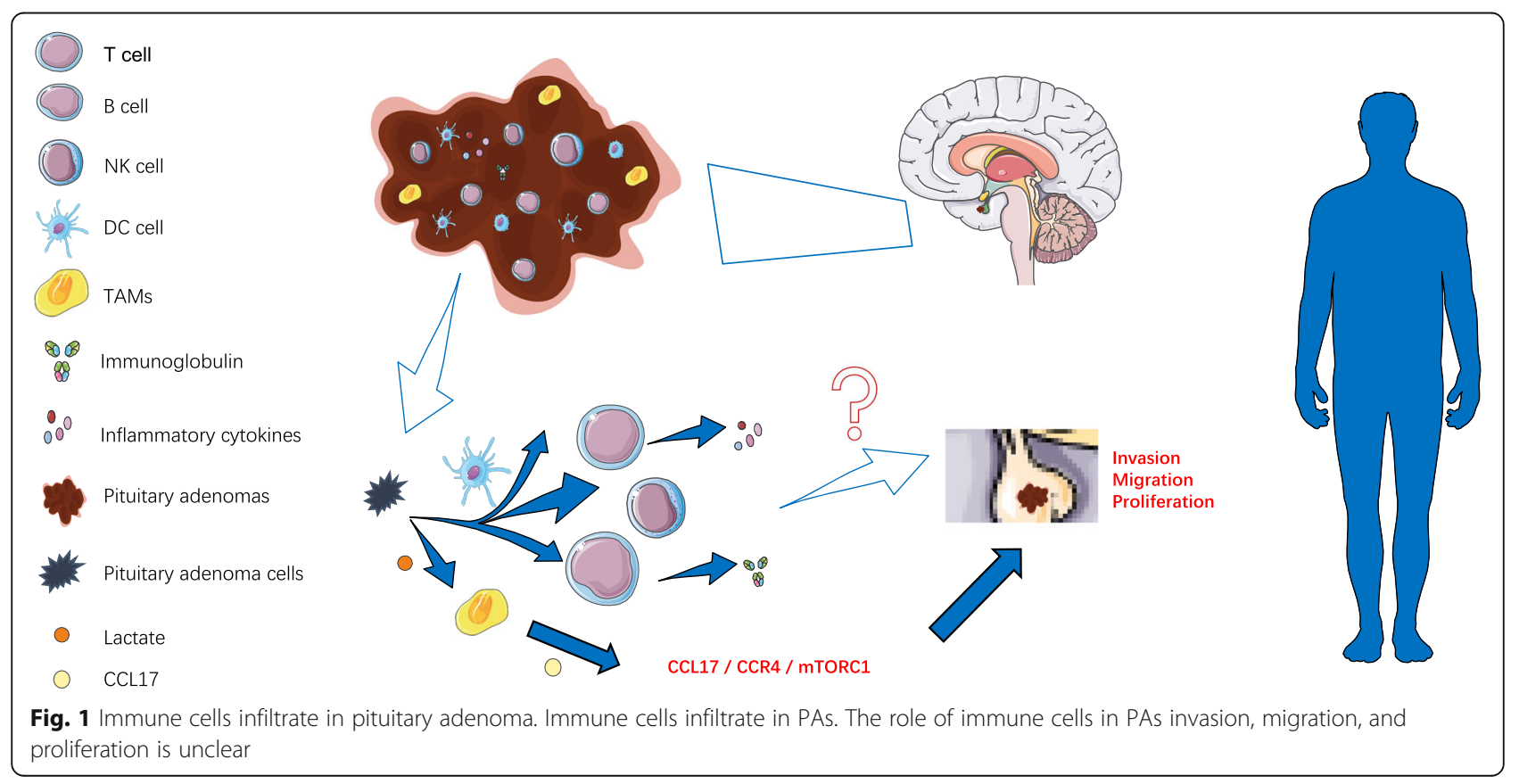


resulting in TME acidification, which reshapes TAMs into an M2-type phenotype and then secrets CCL17 through TAMs to enhance tumor invasion through the CCL17/CCR4/mTORC1 axis [31]. Meanwhile, M2 macrophages may play a role in neoangiogenesis in pituitary adenomas together with B cells, CD $4{ }^{+} \mathrm{T}$ cells, and Foxp3 + lymphocytes [32]. Dendritic cells (DCs) are the main antigen-presenting cells and serve as a bridge between adaptive and innate immune systems [33]. DCs promotes tumorigenesis in some tumors and inhibits tumorigenesis in others, which indicates the phenomenon of tumor stage dependence, that is, DCs show tumor inhibition effect in the early stage, but with the tumor promotion, it can be changed to promote the development of the tumor [33]. A key part of the adaptive immune response is $\mathrm{CD} 4^{+} \mathrm{T}$ and $\mathrm{CD} 8^{+} \mathrm{T}$ cells $[34$, 35]. Current studies have shown that $\mathrm{CD} 4^{+} \mathrm{T}$ cells mediate anti-tumor responses through a variety of mechanisms, such as the CCR5 ligand that acts as the center of $\mathrm{CD}^{+}$and $\mathrm{CD}^{+} \mathrm{T}$ cell activation. $\mathrm{CD}^{+} \mathrm{T}$ cells destroy target cells by differentiating into cytotoxic $\mathrm{T}$ cells (CTLS), releasing cytotoxic particles [36]. In addition, B cell subsets have immunosuppressive and/or regulatory functions and may play a key role in regulating the human immune response to tumors [37].

Research conducted by Wang et al. showed that there is a different distribution of tumor-infiltration immune cells (TIICs) between PAs and the normal pituitary gland, and there are also differences among different PA subtypes. In addition, three immune clusters can be identified among PAs according to their distribution, and each one of PAs shows unique characteristics [38]. PAs can be classified into functional pituitary adenomas (FPAs) and non-functional pituitary adenomas (NFPAs) according to the hormone secretion [39]. FPAs include prolactinomas, somatotroph, corticotroph, thyrotrophin, and rarely gonadotroph adenomas [40]. Existing studies have shown that immune cells infiltrate differently in both FPAs and NFPAs [14, 41-43]. According to imaging characteristics and pathological diagnosis, PAs can be divided into invasive PAs and non-invasive PAs [44, 45]. There are also inconsistencies in the distribution of infiltrating immune cells in PAs, depending on the aggressiveness [46, 47]. For example, the infiltration of $\mathrm{CD}^{+} \mathrm{T}$ cells was positively correlated with PRL and PRL and $\mathrm{GH}$ immunostaining in the tumor and was also positively correlated with the invasions of PAs [41, 48]. The research of recent years has been recently reviewed by us and is presented in Table $1[5,14,32,41,42,47-$ 59]. It is worth noting that the role of immune cells in PAs is not yet clear and may vary among different tumor stages and types. Therefore, before the exact role of immune cells in pituitary tumors is understood, it is necessary to define the immune characteristics of PAs [59].

\section{Inflammatory factors associated with PAs}

Current research has shown that cytokines including interferon (IFN), interleukin insurance-linked securities (ILs), and tumor necrosis factor (TNF) play a key role in the differentiation of the pituitary gland and oncogenesis of PAs [60, 61]. T helper type 1 (Th1) cells secrete TNF$\alpha$, IFN- $\gamma$, and IL-2, and they induce cell-mediated immune responses, whereas Th2 cells secrete IL-4, IL-5, IL-6, IL-10, and IL-13 [60]. IFN is divided into type I and type II. The main classes of type I IFN are IFN- $\alpha$, IFN- $\beta$, IFN- $\varepsilon$, IFN- $\kappa$, and IFN- $\omega$. IFN- $\gamma$ belongs to type II IFN [62]. IFNs play a regulatory role in pituitary hormone secretion. Both stimulatory and inhibitory effects of IFNs (IFN $\alpha$ and IFN $\gamma$ ) on the secretion of ACTH, PRL, and GH have been reported [63]. IFN- $\alpha$ significantly inhibits hormone secretion and intracellular hormone concentration in human GH secreting PAs, prolactin, and NFPAs or gonadotropin adenoma [63]. TNF can trigger a variety of potential outcomes through TNFR1 and TNFR2 activation signals, including cell proliferation, gene activation, or cell death [64]. In invasive PAs, TNF- $\alpha$ promotes pathological osteoclast formation by directly inducing osteoclast differentiation, leading to inflammatory bone destruction [65]. Therefore, Zhu et al. proposed that TNF- $\alpha$ might be a novel target in the treatment of osteo-invasive pituitary adenoma [66]. TNF- $\alpha$ also may be an important regulator of hemorrhagic transformation in pituitary adenomas indicated by the finding that hemorrhagic pituitary adenomas displayed higher protein and mRNA levels of TNF- $\alpha$ [67]. The function of ILs is related to the expression and regulation of the immune response, which is involved in many factors originating from lymphocytes or macrophages. Qiu et al. reported that in the serum of patients with PAs (include invasive and non-invasive PAs), IL-4, IL-5, and IL-17A were significantly increased, while Th1/Th2 ratio was significantly decreased [60]. Notably, serum IL-17A levels in patients with invasive PA reported in this study were significantly higher than those in patients with non-invasive PA. While another study showed no significant difference between serum IL-17A levels and PA growth types [68]. In addition, the serum level of IL-4 was significantly higher in patients with idiopathic hyperprolactinemia [69]. The bidirectional role of IL-6 in PAs has also been reported. Paracrine IL- 6 may be a condition that permits the growth of pituitary cells by contributes to excessive hormone production, growth, and neovascularization of pituitary adenomas, while autocrine IL-6 inhibits the aggressive growth and malignant transformation of tumors [70]. In vitro studies, an earlier study showed that IL-2 and IL-6 stimulated the proliferation of GH3 cells [71]. Furthermore, other inflammatory factors 
Table 1 Immune studies of PAs

\begin{tabular}{|c|c|c|c|c|c|}
\hline $\begin{array}{l}\text { Cell type and } \\
\text { marker }\end{array}$ & Conclusion/distribution & Ref. & Population & Methods & Year \\
\hline CD3 (T cells) & $\begin{array}{l}\text { FPAs > NFPAs; GH adenomas > ACTH adenomas > PRL } \\
\text { adenomas. }\end{array}$ & {$[5,49]$} & $67 ; 48$ & Immunohistochemistry & $2020 ; 2016$ \\
\hline CD4 (T cells) & $\begin{array}{l}\text { FPAs > NFPAs; GH adenomas > non-GH adenomas. T cell } \\
\text { phenotype was the } \mathrm{CD} 4^{+} \text {memory resting phenotype. May } \\
\text { have angiogenic effects. }\end{array}$ & $\begin{array}{l}{[32,41} \\
48,49]\end{array}$ & $\begin{array}{l}24 ; 134 ; 35 ; \\
48\end{array}$ & Immunohistochemistry & $\begin{array}{l}2020 ; 2020 ; \\
2015 ; 2016\end{array}$ \\
\hline CD8 (T cells) & $\begin{array}{l}\text { GH adenomas > non-GH adenomas. Positively correlated with } \\
\text { serum PRL and intratumoral immunostaining of PRL and GH. } \\
\text { Cavernous sinus invasion > non-invasive tumors. The number } \\
\text { of CD8 } 8^{+} \text {Iymphocytes was positively correlated with the num- } \\
\text { ber of CD } 68^{+} \text {macrophages. FPAs }>\text { NFPAs (especially GHo- } \\
\text { mas). Cushing pituitary tumors had higher CD8 }{ }^{+} T \text { cells. }\end{array}$ & $\begin{array}{l}{[41,42,} \\
48,50- \\
52]\end{array}$ & $\begin{array}{l}134 ; 191 ; \\
35 ; 27 ; 64 ; \\
115\end{array}$ & $\begin{array}{l}\text { Immunohistochemistry; } \\
\text { Computational approach; } \\
\text { RNA-seq.; }\end{array}$ & $\begin{array}{l}\text { 2020; 2018; } \\
\text { 2015; 2019; } \\
2020 ; 2020\end{array}$ \\
\hline $\begin{array}{l}\text { FOXP3 } \\
\text { (regulatory } T \\
\text { cells) }\end{array}$ & $\begin{array}{l}\text { AlP-mutated GH tumors > sporadic ones and NPG. Cavernous } \\
\text { sinus invasion > non-invasive tumors. May have angiogenic } \\
\text { effects. }\end{array}$ & $\begin{array}{l}{[32,50,} \\
53]\end{array}$ & $24 ; 27 ; 15$ & Immunohistochemistry & $\begin{array}{l}\text { 2020; 2019; } \\
2019\end{array}$ \\
\hline CD20 (B cells) & $\begin{array}{l}\text { FPAs > NFPAs (especially GHomas). May have angiogenic } \\
\text { effects. }\end{array}$ & {$[32,52]$} & $24 ; 115$ & $\begin{array}{l}\text { Immunohistochemistry; } \\
\text { RNA-seq. }\end{array}$ & 2020; 2020 \\
\hline $\begin{array}{l}\text { CD45 } \\
\text { (lymphocytes) }\end{array}$ & $\begin{array}{l}\text { The CD45 staining in pituitary adenomas was significantly } \\
\text { greater than that in normal pituitary. There was no statistically } \\
\text { significant difference among the various secretory types. High } \\
\text { (MIB-1 }>3 \% \text { ) proliferative indices > low (MIB-1 } \leq 3 \% \text { ) } \\
\text { proliferative indices. }\end{array}$ & {$[49,54]$} & $48 ; 72$ & Immunohistochemistry & $2016 ; 2010$ \\
\hline $\begin{array}{l}\text { CD68 } \\
\text { (macrophages) }\end{array}$ & $\begin{array}{l}\text { The numbers of } \mathrm{CD}^{+} 8^{+} \text {cells showed a positive correlation } \\
\text { with the tumor sizes and Knosp classification grades. Sparsely } \\
\text { granulated GH and null cell tumors > densely granulated GH } \\
\text { and ACTH tumors. AIP-mutated GH tumors > sporadic ones } \\
\text { and NPG. The number of CD8 } 8^{+} \text {lymphocytes was positively } \\
\text { correlated with the number of CD } 68^{+} \text {macrophages. Gonado- } \\
\text { troph PitNETs present an increased CD68 } 68^{+} \text {macrophage signa- } \\
\text { ture compared to somatotroph, lactotroph, and corticotroph } \\
\text { PitNETs. The percentage of CD } 68^{+} \text {and CD } 163^{+} \text {infiltrating } \\
\text { macrophages was significantly associated with the aggressive- } \\
\text { ness of gonadotropin tumors. Macrophages and NK cells are } \\
\text { positively correlated. M2 macrophages }>\text { M1 macrophages. In } \\
\text { the PA stroma, CD68+ macrophages }>C D 4+T \text { cells and } \\
\text { CD8+ T cells. }\end{array}$ & $\begin{array}{l}{[31,41} \\
47,48 \\
51-53]\end{array}$ & $\begin{array}{l}35 ; 134 ; 28 ; \\
35 ; 64 ; 115 ; \\
15\end{array}$ & $\begin{array}{l}\text { Immunohistochemistry; } \\
\text { Computational approach; } \\
\text { flow cytometry }\end{array}$ & $\begin{array}{l}2021 ; 2020 ; \\
2020 ; 2015 ; \\
2020 ; 2020 ; \\
2019\end{array}$ \\
\hline CD147 & Invasion tumors > non-invasive tumors. & [55] & 55 & Immunohistochemistry & 2005 \\
\hline CD163 & $\begin{array}{l}\text { The most abundant type of immune cell in PitNETs, and } \\
\text { mainly CD163 +. }\end{array}$ & [14] & 45 & immunohistochemistry & 2019 \\
\hline NK cells & Macrophages and NK cells are positively correlated. & [52] & 115 & $\begin{array}{l}\text { Immunohistochemistry; } \\
\text { RNA-seq. }\end{array}$ & 2020 \\
\hline Neutrophils & $\begin{array}{l}\text { PitNETs contained fewer neutrophils. NF-PitNETs had more } \\
\text { neutrophils than somatotropinomas. }\end{array}$ & [14] & 45 & Immunohistochemistry & 2019 \\
\hline CTLA-4 & $\begin{array}{l}\text { There was no significant difference in CTLA-4 expression } \\
\text { among tumor subtypes. }\end{array}$ & {$[52]$} & 115 & $\begin{array}{l}\text { Immunohistochemistry; } \\
\text { RNA-seq. }\end{array}$ & 2020 \\
\hline PD-1 & $\begin{array}{l}\text { NFPAs }>\text { FPAs (especially GHomas). High (MIB- } 1>3 \% \text { ) } \\
\text { proliferative indices }>\text { low (MIB-1 } \leq 3 \% \text { ) proliferative indices. }\end{array}$ & {$[49,52]$} & $48 ; 115$ & Immunohistochemistry & $2016 ; 2020$ \\
\hline PD-L1 & $\begin{array}{l}\text { FPAs > NFPAs (especially GHomas). Positively correlated with } \\
\text { serum PRL and intratumoral immunostaining of PRL and GH. } \\
\text { The score tended to be higher }(p=0.050) \text { in the cavernous } \\
\text { sinus invasion group. There was no difference between } \\
\text { primary and recurrent adenomas. }\end{array}$ & $\begin{array}{l}{[5,42} \\
49,50 \\
52,56]\end{array}$ & $\begin{array}{l}67 ; 191 ; \\
48 ; 27 ; 115 \\
55 .\end{array}$ & $\begin{array}{l}\text { Immunohistochemistry; } \\
\text { RNA-seq. }\end{array}$ & $\begin{array}{l}2020 ; 2018 ; \\
2016 ; 2019 ; \\
2020 ; 2020\end{array}$ \\
\hline
\end{tabular}

Abbreviations: FPAs functional pituitary adenoma, NFPAs non-functional pituitary adenoma, GH growth hormone, PRL prolactin, ACTH adrenocorticotropic hormone, FoxP3 forkhead box protein P3, NK cell natural killer cell, PitNETs pituitary neuroendocrine tumor, NPG normal pituitary glands, AIP aryl hydrocarbon receptorinteracting protein, CTLA-4 co-inhibitory cytotoxic T lymphocyte-associated protein 4

present in TME also play complex roles that require further detailed exploration by researchers. For example, macrophage migration inhibitory factor (MIF) is an immunomodulator that can be induced by pituitary hormones, enhancing the production of inflammatory cytokines such as TNF, IL1 , and IFN, to play its role of anti-tumor or tumor promotion [72]. 


\section{Status of immunotherapy for PAs}

The relationship between tumor cells and the immune system is divided into three stages according to the theory proposed by Jun et al., at the initial stage, tumor cells are recognized and cleared by immune cells. As tumors develop, there is a phase of balance between tumor cells and immune cells. Eventually, the immune response is evaded by the tumor cells, and the immune system is unable to cope with the tumors [73]. As the tumor grows and changes, tumor cells can evade the immune system, leading to further spread, infiltration, and even metastasis. This kind of avoidance is achieved by the costimulation and co-inhibition signals of tumor cells [74]. The immune checkpoint is a regulator of immune activation and plays an important role in maintaining selftolerance, controlling immune response intensity, and reducing tissue damage [75]. Immune checkpoints can be used by tumors to suppress $\mathrm{T}$ cell activation. The most representative ones are the co-inhibitory cytotoxic $\mathrm{T}$ lymphocyte-associated protein 4 (CTLA-4) and programmed cell death 1 (PD-1) pathways. T cell dysfunction, failure, and neutralization in tumors can be caused by activation of the PD-1 signaling pathway [76]. CTLA4 is expressed in various types of tumors including PAs and can play a role by limiting the $C D 4^{+} \mathrm{T}$ cell phenotype $[77,78]$. As a result, blocking immune checkpoints is a new approach to the treatment of many types of tumors [79]. PD-L1 binds to the PD-1 receptor on activated $\mathrm{T}$ cells and inhibits the cytotoxic anti-tumor function of $\mathrm{T}$ cells while blocking this interaction can produce a lasting $\mathrm{T}$ cell response [80-82]. Blocking CTLA-4 receptors on lymphocytes leads to $T$ cell activation, which reduces tumor-mediated immune tolerance [83]. When the CTLA-4 and PD-1 are blocked, the stimulation signal of $\mathrm{T}$ cells are activated, the number of cytotoxic $\mathrm{T}$ cells with anti-tumor activity increase, the production and proliferation of pro-inflammatory cytokines can also be promoted, and finally, the tumor destruction can be accelerated $[84,85]$. While antiprogrammed cell death protein 1 (anti-PD-1) and anticytotoxic T-lymphocyte-associated protein 4 (antiCTLA4) antibodies have been extensively used to target immune checkpoints in many cancers, their use in pituitary tumors has just commenced.

Recently, it has been reported that PD-L1 expression is higher in pituitary tumors invading the cavernous sinus [86]. In addition, the expression of PD-L1 also significantly increased with the increase of serum GH, PRL, $\mathrm{ACTH}$, and cortisol levels [42]. Similar conditions also exist in the expression of PD-1 [49, 52]. However, no significant difference was found in CTLA4 expression [52]. In animal experiments, Hanna $\mathrm{R}$ et al. provided a new theoretical basis for the immunotherapy of PAs, that is, anti-PD-L1 treatment successfully reduced the plasma ACTH level of model mice, reduced the growth of PAs, and improved the survival rate of model mice [5]. In clinical application, a patient with ACTHsecreting pituitary carcinoma who received clinical remission using ipilimumab (anti-CTLA-4) and nivolumab (anti-PD-1) ICI was reported by Sol et al. [87]. Moreover, immune checkpoints such as TIM3 and LAG3 are also potential targets for immunotherapy of pituitary adenomas [88]. In addition to immune checkpoints, other methods of immunotherapy are being explored. Hazrati et al. published a report of a female with a macroprolactinoma refractory to conventional therapy and was successfully treated with immunotherapy. A Th1 activator adjuvant was inoculated with autoantigens weekly for 24 weeks, and following this therapy, her serum prolactin levels decreased and adenoma almost disappeared [89]. However, the side effects of immunotherapy are varied and any organ (skin, intestines, liver, and glands like the thyroid and adrenal glands) may be affected, leading to a variety of diseases (rash, pruritus, vitiligo, diarrhea, colitis, hepatitis, hypophysitis, hypothyroidism, primary adrenal insufficiency, and diabetes) $[90,91]$. So, further studies are needed to refine the immunotherapy regimen for PAs. For example, immunotherapy combined with radiation therapy may be a promising option [92].

\section{Future perspectives and conclusions}

At present, the specific mechanism of the interaction between pituitary adenoma and the human immune system is not clear, and studies are limited to the apparent expression level of related markers. However, based on the existing evidence, namely, the expression of immune cells and the changes and differences of inflammatory factors in pituitary adenomas, the immune research on pituitary adenomas deserves further study. The following points may be the direction of efforts: (1) comprehensive analysis of the expression of different immune cells and immune factors in the same batch of samples. (2) The study should be conducted in different types of pituitary adenomas. (3) Further mechanism study based on the current apparent expression research. (4) Exploration of new immune cell types and immune factors. At the same time, the exploration of immunotherapy also provides a new choice for the treatment of PAs. It should also be kept in mind that the immune response is dynamic during tumor development and that there may be interpatient heterogeneity. Individualized immunotherapy strategies for individual patients at different stages are very important. Therefore, it is necessary to determine the immune landscape and its mechanism changes in pituitary adenoma, which is undoubtedly a challenge for researchers. 


\section{Abbreviations}

PAs: Pituitary adenomas; TME: Tumor microenvironment; NK: Natural killer; ECM: Extracellular matrix; TMICs: Tumor microenvironmental immune cells; TLS: Tertiary lymphoid structures; TAM: Macrophages; DCs: Dendritic cells; CTLS: Cytotoxic T cells; FPAs: Functional pituitary adenomas; NFPAs: Nonfunctional pituitary adenomas; TIICs: Tumor-infiltration immune cells; IFN: Interferon; ILs: Interleukin insurance-linked securities; TNF: Tumor necrosis factor; MIF: Macrophage migration inhibitory factor; CTLA-4: Coinhibitory cytotoxic T lymphocyte-associated protein 4; PD-1: Programmed cell death 1

\section{Acknowledgements}

None.

\section{Authors' contributions}

Ding Nie and Qiuyue Fang carried out the studies. Ding Nie participated in collecting the data and drafted the manuscript. Jianhua Cheng and Bin Li analyzed the data. Chuzhong Li and Songbai Gui directed the writing. Yazhuo Zhang and Peng Zhao helped to revise the manuscript. The authors read and approved the final manuscript.

\section{Funding}

No funding.

Availability of data and materials

Not applicable.

\section{Declarations}

Ethics approval and consent to participate

Not applicable.

\section{Consent for publication}

Not applicable.

\section{Competing interests}

The authors declare that they have no competing interests.

\section{Author details}

'Department of Neurosurgery, Beijing Tiantan Hospital, Capital Medical University, Beijing, China. ${ }^{2}$ Beijing Neurosurgical Institute, Beijing, China.

\section{Received: 3 February 2021 Accepted: 20 May 2021}

Published online: 05 June 2021

\section{References}

1. Fabio G, et al. Pituitary adenoma and the chemokine network: a systemic view. Front Endocrinol. 2015;6:141.

2. Di leva A, et al. Aggressive pituitary adenomas_diagnosis and emerging treatments. Nat Rev Endocrinol. 2014;10(7):423-35. https://doi.org/10.1038/ nrendo.2014.64.

3. Hansen TM, Batra S, Lim M, et al. Invasive adenoma and pituitary carcinoma: a SEER database analysis. Neurosurg Rev. 2014;37(2):279-86. https://doi. org/10.1007/s10143-014-0525-y.

4. Heaney AP. Clinical review: Pituitary carcinoma: difficult diagnosis and treatment [published correction appears in J Clin Endocrinol Metab. 2012 Mar;97(3):1064]. J Clin Endocrinol Metab. 2011;96(12):3649-60. https://doi. org/10.1210/jc.2011-2031.

5. Kemeny HR, Elsamadicy AA, Farber SH, Champion CD, Lorrey SJ, Chongsathidkiet $\mathrm{P}$, et al. Targeting PD-L1 initiates effective antitumor immunity in a murine model of cushing disease. Clin Cancer Res. 2020;26(5): 1141-51. https://doi.org/10.1158/1078-0432.CCR-18-3486.

6. Dai W, Zhuang Z, Ling H, Yang Y, Hang C. Systematic review and network meta-analysis assess the comparative efficacy and safety of transsphenoidal surgery for pituitary tumor. Neurosurg Rev. 2021;44(1):515-27. https://doi. org/10.1007/s10143-020-01240-3.

7. Almutairi $R$, et al. Gross total resection of pituitary adenomas after endoscopic vs. microscopic transsphenoidal surgery: a meta-analysis. Acta Neurochir. 2018;160(5):1005-21. https://doi.org/10.1007/s00701-017-3438-z.

8. Lamb LS, Sim H-W, McCormack Al. Exploring the role of novel medical therapies for aggressive pituitary tumors: a review of the literature- "are we there yet?". Cancers. 2020;12(2):308. https://doi.org/10.3390/cancers120203 08.

9. Maghathe T, Miller WK, Mugge L, Mansour TR, Schroeder J. Immunotherapy and potential molecular targets for the treatment of pituitary adenomas resistant to standard therapy: a critical review of potential therapeutic targets and current developments. J Neurosurg Sci. 2020;64(1):71-83. https://doi.org/10.23736/S0390-5616.18.04419-3.

10. Suojun Z, Feng W, Dongsheng G, Ting L. Targeting Raf/MEK/ERK pathway in pituitary adenomas. Eur J Cancer. 2012;48(3):389-95. https://doi.org/10.1016/ j.ejca.2011.11.002.

11. Strathmann FG, Borlee G, Born DE, Gonzalez-Cuyar LF, Huber BR, Baird GS. Multiplex immunoassays of peptide hormones extracted from formalinfixed, paraffin-embedded tissue accurately subclassify pituitary adenomas. Clin Chem. 2012:58(2):366-74.

12. Dragomir MP, Moisoiu V, Manaila R, et al. A holistic perspective: exosomes shuttle between nerves and immune cells in the tumor microenvironment. J Clin Med. 2020;9(11):3529. https://doi.org/10.3390/jcm9113529.

13. Zhang J, Gu C, Song Q, Zhu M, Xu Y, Xiao M, et al. Identifying cancerassociated fibroblasts as emerging targets for hepatocellular carcinoma. Cell Biosci. 2020;10(1):127. https://doi.org/10.1186/s13578-020-00488-y.

14. Marques P, Barry S, Carlsen E, Collier D, Ronaldson A, Awad S, et al. Chemokines modulate the tumour microenvironment in pituitary neuroendocrine tumours. Acta Neuropathol Commun. 2019;7(1):172. https:// doi.org/10.1186/s40478-019-0830-3.

15. Buchta Rosean CM. and M.R. Rutkowski, The influence of the commensal microbiota on distal tumor-promoting inflammation. Semin Immunol. 2017; 32:62-73. https://doi.org/10.1016/j.smim.2017.06.002.

16. Hajjo H, Geva-Zatorsky N. Gut microbiota-host interactions now also brainimmune axis. Curr Opin Neurobiol. 2020;62:53-9. https://doi.org/10.1016/j. conb.2019.10.009.

17. Yong SB, Chung JY, Song Y, Kim J, Ra S, Kim YH. Non-viral nanoimmunotherapeutics targeting tumor microenvironmental immune cells. Biomaterials. 2019;219:119401. https://doi.org/10.1016/j.biomaterials.2019.11 9401.

18. Belli C, Trapani D, Viale G, D'Amico P, Duso BA, Della Vigna P, et al. Targeting the microenvironment in solid tumors. Cancer Treat Rev. 2018;65: 22-32. https://doi.org/10.1016/j.ctrv.2018.02.004.

19. Hui L, Chen Y. Tumor microenvironment: sanctuary of the devil. Cancer Lett. 2015;368(1):7-13. https://doi.org/10.1016/j.canlet.2015.07.039.

20. Ilie MD, Vasiljevic A, Raverot G, Bertolino P. The microenvironment of pituitary tumors-biological and therapeutic implications. Cancers. 2019; 11(10):1605. https://doi.org/10.3390/cancers11101605.

21. Ramaswamy K. Human Immune System; 2003.

22. Chiossone L, Dumas PY, Vienne M, Vivier E. Natural killer cells and other innate lymphoid cells in cancer. Nat Rev Immunol. 2018;18(11):671-88. https://doi.org/10.1038/s41577-018-0061-z.

23. Malmberg KJ, Carlsten M, Björklund A, Sohlberg E, Bryceson YT, Ljunggren HG. Natural killer cell-mediated immunosurveillance of human cancer. Semin Immunol. 2017;31:20-9. https://doi.org/10.1016/j. smim.2017.08.002.

24. Ljunggren HG, Kärre K. In search of the 'missing self': MHC molecules and NK cell recognition. Immunol Today. 1990;11(7):237-44. https://doi.org/10.1 016/0167-5699(90)90097-S.

25. Garrido F. MHC/HLA Class I Loss in Cancer Cells. Adv Exp Med Biol. 2019; 1151:15-78. https://doi.org/10.1007/978-3-030-17864-2_2.

26. Dendrou CA, Petersen J, Rossjohn J, Fugger L. HLA variation and disease. Nat Rev Immunol. 2018;18(5):325-39. https://doi.org/10.1038/nri.2017.143.

27. Walzer T, Blery M, Chaix J, Fuseri N, Chasson L, Robbins SH, et al. Identification, activation, and selective in vivo ablation of mouse NK cells via NKp46. Proc Natl Acad Sci U S A. 2007;104(9):3384-9. https://doi.org/10.1 073/pnas.0609692104.

28. Weil S, et al. Natural killer group 2D ligand depletion reconstitutes natural killer cell immunosurveillance of head and neck squamous cell carcinoma. Front Immunol. 2017:8:387.

29. Yang L, Zhang $Y$. Tumor-associated macrophages: from basic research to clinical application. J Hematol Oncol. 2017;10(1):58. https://doi.org/10.1186/ s13045-017-0430-2.

30. Grivennikov SI, Greten FR, Karin M. Immunity, inflammation, and cancer. Cell. 2010;140(6):883-99. https://doi.org/10.1016/j.cell.2010.01.025.

31. Zhang $A, X u Y, X u H$, Ren J, Meng T, Ni Y, et al. Lactate-induced $M 2$ polarization of tumor-associated macrophages promotes the invasion of 
pituitary adenoma by secreting CCL17. Theranostics. 2021;11(8):3839-52. https://doi.org/10.7150/thno.53749.

32. Marques P, Barry S, Carlsen E, Collier D, Ronaldson A, Dorward N, et al. The role of the tumour microenvironment in the angiogenesis of pituitary tumours. Endocrine. 2020;70(3):593-606. https://doi.org/10.1007/s12020-02002478-z.

33. Hinshaw DC, Shevde LA. The tumor microenvironment innately modulates cancer progression. Cancer Res. 2019;79(18):4557-66. https://doi.org/10.11 58/0008-5472.CAN-18-3962

34. Hashimoto M, Kamphorst AO, Im SJ, Kissick HT, Pillai RN, Ramalingam SS, et al. CD8 T cell exhaustion in chronic infection and cancer: opportunities for interventions. Annu Rev Med. 2018;69(1):301-18. https://doi.org/10.114 6/annurev-med-012017-043208.

35. Tay RE, Richardson EK, Toh HC. Revisiting the role of CD4(+) T cells in cancer immunotherapy-new insights into old paradigms. Cancer Gene Ther. 2021;28(1-2):5-17. https://doi.org/10.1038/s41417-020-0183-x.

36. Sadeghi Rad H, Monkman J, Warkiani ME, et al. Understanding the tumor microenvironment for effective immunotherapy. Med Res Rev. 2021;41(3): 1474-98. https://doi.org/10.1002/med.2176.

37. Zhang $Y$, Gallastegui N, Rosenblatt JD. Regulatory B cells in anti-tumor immunity. Int Immunol. 2015;27(10):521-30. https://doi.org/10.1093/intimm/ dxv034.

38. Wang Z, Guo X, Gao L, Deng K, Lian W, Bao X, et al. The immune profile of pituitary adenomas and a novel immune classification for predicting immunotherapy responsiveness. J Clin Endocrinol Metab. 2020;105(9): e3207-23. https://doi.org/10.1210/clinem/dgaa449.

39. Aflorei $\mathrm{E}$, Korbonits $\mathrm{M}$. Epidemiology and etiopathogenesis of pituitary adenomas. J Neuro-Oncol. 2014;117(3):379-94. https://doi.org/10.1007/s11 060-013-1354-5.

40. Varlamov E, McCartney S, Fleseriu M. Functioning pituitary adenomas current treatment options and emerging medical therapies. Eur Endocrinol. 2019:15(1):30-40. https://doi.org/10.17925/EE.2019.15.1.30.

41. Yeung JT, Vesely MD, Miyagishima DF. In silico analysis of the immunological landscape of pituitary adenomas. J Neurooncol. 2020;147(3): 595-8. https://doi.org/10.1007/s11060-020-03476-X.

42. Wang PF, Wang TJ, Yang YK, Yao K, Li Z, Li YM, et al. The expression profile of PD-L1 and CD8(+) lymphocyte in pituitary adenomas indicating for immunotherapy. J Neurooncol. 2018;139(1):89-95. https://doi.org/10.1007/ s1 1060-018-2844-2

43. Salomon MP, Wang X, Marzese DM, Hsu SC, Nelson N, Zhang X, et al. The epigenomic landscape of pituitary adenomas reveals specific alterations and differentiates among acromegaly, Cushing's disease and endocrine-inactive subtypes. Clin Cancer Res. 2018;24(17):4126-36. https://doi.org/10.1158/1 078-0432.CCR-17-2206.

44. Trouillas J, et al. A new prognostic clinicopathological classification of pituitary adenomas: a multicentric case-control study of 410 patients with 8 years post-operative follow-up. Acta Neuropathol. 2013;126(1):123-35. https://doi.org/10.1007/s00401-013-1084-y.

45. Fleseriu M, Popovic $\mathrm{V}$. The journey in diagnosis and treatment, from pituitary adenoma to aggressive pituitary tumors. Rev Endocr Metab Disord. 2020;21(2):201-2. https://doi.org/10.1007/s11154-020-09561-w.

46. Principe, M., et al., Immune landscape of pituitary neuroendocrine tumours reveals association between macrophages and gonadotroph-tumour invasion. J Clin Endocrinol Metab, 2020.

47. Principe M, Chanal M, Ilie MD, et al. Immune landscape of pituitary tumors reveals association between macrophages and gonadotroph tumor invasion. J Clin Endocrinol Metab. 2020;105(11):dgaa520. https:// doi.org/10.1210/clinem/dgaa520

48. Lu JQ, Adam B, Jack AS, Lam A, Broad RW, Chik CL. Immune cell infiltrates in pituitary adenomas: more macrophages in larger adenomas and more cells in growth hormone adenomas. Endocr Pathol. 2015;26(3):263-72. https://doi.org/10.1007/s12022-015-9383-6.

49. Mei Y, Bi WL, Greenwald NF, du Z, Agar NYR, Kaiser UB, et al. Increased expression of programmed death ligand 1 (PD-L1) in human pituitary tumors. Oncotarget. 2016;7(47):76565-76. https://doi.org/10.18632/oncota rget.12088.

50. Sato M, Tamura $\mathrm{R}$, Tamura $\mathrm{H}$, et al. Analysis of tumor angiogenesis and immune microenvironment in non-functional pituitary endocrine tumors. $J$ Clin Med. 2019;8(5):695. https://doi.org/10.3390/jcm8050695.

51. lacovazzo D, Chiloiro S, Carlsen E, Bianchi A, Giampietro A, Tartaglione T, et al. Tumour-infiltrating cytotoxic T lymphocytes in somatotroph pituitary neuroendocrine tumours. Endocrine. 2020;67(3):651-8. https://doi.org/10.1 007/s12020-019-02145-y.

52. Zhou W, Zhang C, Zhang D, Peng J, Ma S, Wang X, et al. Comprehensive analysis of the immunological landscape of pituitary adenomas: implications of immunotherapy for pituitary adenomas. J Neurooncol. 2020;149(3):47387. https://doi.org/10.1007/s11060-020-03636-z.

53. Barry S, Carlsen E, Marques P, Stiles CE, Gadaleta E, Berney DM, et al. Tumor microenvironment defines the invasive phenotype of AIP-mutation-positive pituitary tumors. Oncogene. 2019;38(27):5381-95. https://doi.org/10.1038/ s41388-019-0779-5.

54. Lupi I, Manetti L, Caturegli P, Menicagli M, Cosottini M, lannelli A, et al. Tumor infiltrating lymphocytes but not serum pituitary antibodies are associated with poor clinical outcome after surgery in patients with pituitary adenoma. J Clin Endocrinol Metab. 2010;95(1):289-96. https://doi. org/10.1210/jc.2009-1583.

55. Gang, $\mathrm{H}$., et al., The study on expression and relationship between matrix metalloproteinase-2 and CD147 in invasive pituitary adenomas. Chinese J Nervous Ment Dis. 2005

56. Zhao G, Chen W, He J, Cui C, Zhao L, Zhao Y, et al. Analysis of cyclooxygenase 2, programmed cell death ligand 1, and arginase 1 expression in human pituitary adenoma. World Neurosur. 2020;144:e660-73. https://doi.org/10.1016/j.wneu.2020.09.031.

57. Rossi ML, Jones NR, Esiri MM, Havas L, Izzi MA, Coakham HB. Mononuclear cell infiltrate and HLA-Dr expression in 28 pituitary adenomas. Tumori. 1990; 76(6):543-7. https://doi.org/10.1177/030089169007600605.

58. Briceno V, Zaidi HA, Doucette JA, Onomichi KB, Alreshidi A, Mekary RA, et al. Efficacy of transsphenoidal surgery in achieving biochemical cure of growth hormone-secreting pituitary adenomas among patients with cavernous sinus invasion: a systematic review and meta-analysis. Neurol Res. 2017; 39(5):387-98. https://doi.org/10.1080/01616412.2017.1296653.

59. Ilie MD, Vasiljevic A, Raverot G, Bertolino P. The microenvironment of pituitary tumors-biological and therapeutic implications. Cancers (Basel). 2019;11(10):1605. https://doi.org/10.3390/cancers11101605.

60. Qiu L, Yang J, Wang H, Zhu Y, Wang Y, Wu Q. Expression of T-helperassociated cytokines in the serum of pituitary adenoma patients preoperatively and postperatively. Med Hypotheses. 2013;80(6):781-6. https://doi.org/10.1016/j.mehy.2013.03.011.

61. Green VL, Atkin SL, Speirs V, Jeffreys RV, Landolt AM, Mathew B, et al. Cytokine expression in human anterior pituitary adenomas. Clin Endocrinol (Oxf). 1996;45(2):179-85. https://doi.org/10.1046/j.1365-2265.1996.d01-1554.x.

62. Pestka $S$, Krause CD, Walter MR. Interferons, interferon-like cytokines, and their receptors. Immunol Rev. 2004;202(1):8-32. https://doi.org/10.1111/j.01 05-2896.2004.00204x.

63. Hofland $\mathrm{L}$, de Herder WW, Waaijers M, Zuijderwijk J, Uitterlinden P, van Koetsveld $\mathrm{P}$, et al. Interferon-alpha-2a is a potent inhibitor of hormone secretion by cultured human pituitary adenomas. J Clin Endocrinol Metab. 1999:84(9):3336-43. https://doi.org/10.1210/jcem.84.9.6005.

64. Gough P, Myles IA. Tumor necrosis factor receptors: pleiotropic signaling complexes and their differential effects. Front Immunol. 2020;11:585880. https://doi.org/10.3389/fimmu.2020.585880.

65. Nanes MS. Tumor necrosis factor-alpha: molecular and cellular mechanisms in skeletal pathology. Gene. 2003;321:1-15. https://doi.org/10.1016/503 78-1119(03)00841-2.

66. Zhu H, Guo J, Shen Y, Dong W, Gao H, Miao Y, et al. Functions and mechanisms of tumor necrosis factor- $a$ and noncoding RNAs in boneinvasive pituitary adenomas. Clin Cancer Res. 2018;24(22):5757-66. https:// doi.org/10.1158/1078-0432.CCR-18-0472.

67. Xiao Z, Liu Q, Mao F, Wu J, Lei T. TNF-a-induced VEGF and MMP-9 expression promotes hemorrhagic transformation in pituitary adenomas. Int J Mol Sci. 2011;12(6):4165-79. https://doi.org/10.3390/ijms12064165.

68. Glebauskiene B, et al. Association of Ki-67 Labelling Index and IL-17A with Pituitary Adenoma. Biomed Res Int. 2018;2018:7490585.

69. Kalsi AK, Halder A, Jain M, Chaturvedi PK, Mathew M, Sharma JB. Association of raised levels of IL-4 and anti-TPO with hyperprolactinemia. Am J Reprod Immunol. 2019;81(3):e13085. https://doi.org/10.1111/aji.13085

70. Sapochnik M, Fuertes M, Arzt E. Programmed cell senescence: role of IL-6 in the pituitary. J Mol Endocrinol. 2017;58(4):R241-r253. https://doi.org/10.153 0/JME-17-0026.

71. Arzt E, Buric R, Stelzer G, Stalla J, Sauer J, Renner U, et al. Interleukin involvement in anterior pituitary cell growth regulation: effects of IL-2 and IL-6. Endocrinology. 1993; 132(1):459-67. https:/doi.org/10.1210/endo.132.1.8419142. 
72. Takahashi N, Nishihira J, Sato Y, Kondo M, Ogawa H, Ohshima T, et al. Involvement of macrophage migration inhibitory factor (MIF) in the mechanism of tumor cell growth. Mol Med. 1998;4(11):707-14. https://doi. org/10.1007/BF03401765.

73. Kishore C, Bhadra P. Bhadra, Current advancements and future perspectives of immunotherapy in colorectal cancer research. Eur J Pharmacol. 2021;893: 173819. https://doi.org/10.1016/j.ejphar.2020.173819.

74. Filin IY, Solovyeva W, Kitaeva KV, Rutland CS, Rizvanov AA. Current trends in cancer immunotherapy. Biomedicines. 2020;8(12):621. https://doi.org/10.33 90/biomedicines8120621

75. Dai C, Liang S, Sun B, Kang J. The Progress of Immunotherapy in Refractory Pituitary Adenomas and Pituitary Carcinomas. Front Endocrinol (Lausanne). 2020;11:608422. https://doi.org/10.3389/fendo.202 0.608422 .

76. Sun Z, Fourcade J, Pagliano O, Chauvin JM, Sander C, Kirkwood JM, et al IL10 and PD-1 Cooperate to Limit the Activity of Tumor-Specific CD8+ T Cells. Cancer Res. 2015;75(8):1635-44. https://doi.org/10.1158/0008-5472.CA N-14-3016.

77. Wei SC, et al. Negative co-stimulation constrains T cell differentiation by imposing boundaries on possible cell states. Immunity. 2019;50(4):10841098.e10.

78. Caturegli P, di Dalmazi G, Lombardi M, Grosso F, Larman HB, Larman T, et al. Hypophysitis secondary to cytotoxic T-lymphocyte-associated protein 4 blockade: insights into pathogenesis from an autopsy series. Am J Pathol. 2016;186(12):3225-35. https://doi.org/10.1016/j.ajpath.2016. 08.020.

79. Weiner DM, Durgin JS, Wysocka M, Rook AH. The immunopathogenesis and immunotherapy of cutaneous T cell lymphoma: part II, current and future approaches. J Am Acad Dermatol. 2021;84(3):597-604. https://doi.org/10.101 6/j.jaad.2020.12.026.

80. Tsushima F, Yao S, Shin T, Flies A, Flies $\mathrm{S}, \mathrm{Xu} \mathrm{H}$, et al. Interaction between $\mathrm{B} 7-\mathrm{H} 1$ and $\mathrm{PD}-1$ determines initiation and reversal of T-cell anergy. Blood. 2007;110(1):180-5. https://doi.org/10.1182/blood-2006-11060087.

81. Taube J, et al. Colocalization of inflammatory response with B7-h1 expression in human melanocytic lesions supports an adaptive resistance mechanism of immune escape. Sci Transl Med. 2012;4(127):127ra37.

82. Pardoll DM. The blockade of immune checkpoints in cancer immunotherapy. Nat Rev Cancer. 2012;12(4):252-64. https://doi.org/10.1038/ nrc3239.

83. Fischli S, Allelein S, Zander T, Henzen C. Endocrinologic side effects of oncologic treatment with anti-CTLA-4-antibodies. Dtsch Med Wochenschr. 2014;139(19):996-1000. https://doi.org/10.1055/s-0034-13 69961.

84. Sharma P, Allison JP. Dissecting the mechanisms of immune checkpoint therapy. Nat Rev Immunol. 2020;20(2):75-6. https://doi.org/10.1038/s41577020-0275-8.

85. Kim DY, Kim PH, Suh CH, Kim KW, Kim HS. Immune checkpoint inhibitors with or without radiotherapy in non-small cell lung cancer patients with brain metastases: a systematic review and meta-analysis. Diagnostics (Basel). 2020;10(12):1098.

86. Sato M, Tamura R, Tamura $H$, et al. Analysis of tumor angiogenesis and immune microenvironment in non-functional pituitary endocrine tumors. J Clin Med. 2019;8(5):695. https://doi.org/10.3390/ jcm8050695.

87. Sol B, de Filette JMK, Awada G, Raeymaeckers S, Aspeslagh S, Andreescu CE, et al. Immune checkpoint inhibitor therapy for ACTH-secreting pituitary carcinoma: a new emerging treatment? Eur J Endocrinol. 2021;184(1):K1-k5. https://doi.org/10.1530/EJE-20-0151.

88. Xu X, Wang D, Wu W, Lu H. Molecular characteristics of genes and the immune microenvironment of a rare chest malignant tumor (pulmonary clear cell sarcoma): a case report. Front Oncol. 2021;11:664883. https://doi. org/10.3389/fonc.2021.664883.

89. Hazrati SM, Aghazadeh J, Mohtarami F, Abouzari M, Rashidi A Immunotherapy of prolactinoma with a T helper 1 activator adjuvant and autoantigens: a case report. Neuroimmunomodulation. 2006;13(4):205-8. https://doi.org/10.1159/000100405.

90. Lakomý R, Poprach A, Kazda T. Management of immune-related endocrinopathies in anticancer treatment with checkpoint inhibitors. Klin Onkol. 2020;33(1):15-9. https://doi.org/10.14735/amko202015.
91. Castinetti F, Albarel F, Archambeaud F, Bertherat J, Bouillet B, Buffier P, et al. French Endocrine Society Guidance on endocrine side effects of immunotherapy. Endocrine-related Cancer. 2019;26(2):G1-G18. https://doi. org/10.1530/ERC-18-0320.

92. Deng $L$, Liang $H$, Burnette $B$, Beckett $M$, Darga $T$, Weichselbaum RR, et al. Irradiation and anti-PD-L1 treatment synergistically promote antitumor immunity in mice. J Clin Invest. 2014;124(2):687-95. https://doi.org/10.1172/ JCl67313.

\section{Publisher's Note}

Springer Nature remains neutral with regard to jurisdictional claims in published maps and institutional affiliations.
Ready to submit your research? Choose BMC and benefit from:

- fast, convenient online submission

- thorough peer review by experienced researchers in your field

- rapid publication on acceptance

- support for research data, including large and complex data types

- gold Open Access which fosters wider collaboration and increased citations

- maximum visibility for your research: over $100 \mathrm{M}$ website views per year

At BMC, research is always in progress.

Learn more biomedcentral.com/submissions 